\title{
RESPONSE OF ONION TO DIFFERENT LEVELS OF IRRIGATION WATER AND FERTILIZATION: (II) BIOMASS, YIELD, SIZE CLASSES, QUALITY, AND WATER USE
}

\author{
Ahmed M. Hassan *
}

ABSTRACT

An experiment was conducted to study the effect of different levels of irrigation water and NPK fertilizers on bulb yield and quality of onion (Allium cepa L.). Four levels of irrigation (65, 75, 85, and 100\% of ETc) and four rates of NPK fertilizers $(0,50,75$, and $100 \%$ of the applied recommended rate of NPK) were arranged in a randomized complete block design, replicated three times. Onion yield, marketable yield, dry bulb yield, total dry biomass, WUE $E_{y}$ of total yield, WUE $E_{m}$ of marketable yield, $W U E_{d}$ of dry yield, TSS, N, $P$, and $K$ were determined under trickle irrigation on a clay loam soil in 2011 and 2012. High yields were observed for the 100 and $85 \%$ ETc with 100 and $75 \%$ NPK treatments. The increase in applied water level significantly decreased the percentage of dry matter and total dry biomass in the onion bulb and the increase in NPK rates increased significantly the percentage of dry matter in the onion bulb in both years. There were no significant effect on WUEy and WUEm when decreasing the water level from $100 \%$ ETc to $85 \%$ ETc and decreasing the NPK rate from $100 \%$ to $75 \%$. The interaction between applied water levels and NPK application rates showed that the maximum significant increase in TSS, $N, P$, and $K$ was with low water levels and higher levels of NPK rates in both 2011 and 2012 seasons.

Key words: trickle irrigation, deficit irrigation, onion, yield, water use efficiency, NPK fertilizer, quality parameters.

\section{INTRODUCTION}

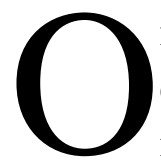
nion (Allium cepa, L.) is one of the most important vegetable crops in the world, it is consumed at its young green stage or after its full development and maturity when it is harvested in the form of a dry bulb. Soil moisture content and application of NPK fertilization influence the production of onion bulbs. Deficit irrigation is a way of maximizing water use efficiency for higher yields per unit of irrigation water applied: the crop is exposed to a certain level of water stress either during a particular period or throughout the whole growing season (Kirda,

* Assis. Prof., Ag. Eng. Dept., Faculty of Ag., Cairo Univ.

Misr J. Ag. Eng., July 2013 
2000). On such strategy currently pursued in many parts of the world is the adoption of deficit irrigation, especially in arid and semi-arid regions. This is an optimization strategy in which irrigation is applied during droughtsensitive growth stages of a crop. Outside these periods, irrigation is limited or even unnecessary if rainfall provides a minimum supply of water. Water restriction is limited to drought-tolerant phonological stages, often the vegetative stages and the late ripening period. Total irrigation application is therefore not proportional to irrigation requirements throughout the crop cycle. While this inevitably results in plant drought stress (Steduto et al., 2009) and consequently in production loss, deficit irrigation maximizes irrigation water productivity (English et al., 1990). The effects of irrigation on yield, water root uptake, shoot density, etc., have been investigated for various crops (Imtiyaz et al., 2000; Camposeo and Rubino, 2003; Jordan et al., 2003; Hanson et al., 2003), but rarely for onion in the context of arid or semi-arid areas. Nevertheless, former studies on the irrigation of onions (Hedge, 1986; Martin de Santa Olalla et al., 1994) concluded that yield depends to a great extent on an appropriate water supply. Shock et al. (2000) found that imposing a soilmatric potential of $<-20 \mathrm{kPa}$ reduced colossal onion yield on the first year and reduced total yield on the second year. Water stress did not affect bulb decomposition during storage in either year. Maximum yield may be obtained with the fulfillment of the entire crop water requirements. However, practicing deficit irrigation could increase the irrigated area or the frequency of cultivation (Samson and Tilahun, 2007). Experiments conducted in Turkey and India indicated that the irrigation water use for cotton could be reduced up to 60 percent of the total crop water requirement with limited yield losses. In this way, high water productivity and better nutrient water balance was obtained (Zwart and Bastiaanssen, 2004). For many crops, high yields as well as high water use efficiency values could have been obtained provided the right choice of the period of water application is made. With a limited yield reduction, the area cropped by some crops could have been also doubled, with a substantial increase in economic returns (Bazza., 1994 ). Certain underutilized and horticultural crops such as quinoa also respond favorably to deficit irrigation when tested at experimental and farmer level for the crop (Geerts et al., 2008). It 
was found that yields could be stabilized at around 1.6 tons per hectare by supplementing irrigation water if rainwater was lacking during the plant establishment and reproductive stages. Also many papers investigated the effects of fertilization application on yield and storability of bulb onions. Application of nitrogen and potassium influenced the different growth components of onion at all the stages of crop growth. $\mathrm{N}$ application generally increased growth parameters of onion plant (Bungard et al., 1999). K plays an important role in the translocation of photosynthates, the added $\mathrm{K}$ might have translocated photosynthates from leaves to bulb, which were further utilized in building up of new cells leading to better height (Singh et al., 2004). The principal aims of onion bulb storage are to maintain the 'quality capital' present at harvest (Gubb and Tavish, 2002) and to satisfy consumer demand for extended period by ensuring the availability of onions of satisfactory quality. Appropriate pre and post harvest treatments are required so that quality factors such as dry matter content, sugars, pungency, skin integrity, skin color, and non-sprouted and un-rotted bulbs can be kept at their optimum level in storage until they reach consumers or market. Nitrogen has an adverse effect on storability of onions. The crop grown with higher doses of $\mathrm{N}$ tend to rot and sprout earlier during storage. Despite the fact that amount and frequency of irrigation influence yield and quality of onions (Kumar et al. 2007).

In this paper, the objective is investigating the effects of deficit irrigation regimes upon water use efficiency, marketable dried bulb yields, and quality of processing onion cultivated under different levels of NPK fertilization.

\section{MATERIALS AND METHODS}

\section{Experimental site}

The study was conducted at the experimental farm of Horticultural Department, Faculty of Agriculture, Omar El-Mukhtar University. The experiment was conducted in 2011 and 2012.

Pegou onion (Allium cepa L.) variety was used for the study. Seedlings were transplanted in the experimental field on furrows of about $25 \mathrm{~cm}$ height, $50 \mathrm{~cm}$ spacing and $16 \mathrm{~m}$ length. A distance of $1 \mathrm{~m}$ was maintained between plots and $1 \mathrm{~m}$ between blocks. Each experimental plot had three 
rows. Table (1) shows the fertilizer sources of NPK and the recommended quantities.

Table (1): The fertilizer sources of NPK and recommended quantities. Fertilizer source Recommended quantity, kg/ha

Urea, $46 \%$ 75

Phosphoric acid $\left(\mathrm{P}_{2} \mathrm{O}_{2}, 80 \%\right)$ 100

Liquid Potassium $\left(\mathrm{K}_{2} \mathrm{O} 36 \%\right)$ 50

\section{Experimental design}

In this study, four crop water requirements (I) and four fertilization treatments (NPK) were designed in open field experiment. The water treatments were $\mathrm{I}_{100}=100 \%, \mathrm{I}_{85}=85 \%, \mathrm{I}_{75}=75 \%$ and $\mathrm{I}_{65}=65 \%$ of crop water requirement) and the fertilization treatments were $\mathrm{NPK}_{100}=100 \%$ dose of N, P and K, NPK $75=75 \%$ dose of N, P and K, $\mathrm{NPK}_{50}=50 \%$ dose of $\mathrm{N}, \mathrm{P}$ and $\mathrm{K}$ and $\mathrm{NPK}_{0}=0 \%$ dose of $\mathrm{N}, \mathrm{P}$ and $\mathrm{K}$. This experimental plan yielded 16 treatments (i.e. $4 \times 4$ ) and each treatment was replicated three times. The trickle irrigation system was used and the emitters were pressure compensated with a flow rate of $4 \mathrm{~L} / \mathrm{h}$, the emitters were spaced at $20 \mathrm{~cm}$ with polyethylene tubes $(16 \mathrm{~mm}$ in external diameter) and $50 \mathrm{~cm}$ spacing between tubes. The treatment combinations were arranged in a Randomized Complete Block Design with three replications.

\section{Measurements}

\subsection{Total applied water of onion}

The total amounts of irrigation water applied (from transplantation to harvest) $I_{100}, I_{85}, I_{75}$, and $I_{65}$ in this study were respectively $564,482,423$, and $368 \mathrm{~mm}$ in 2011 and 582, 494, 436, and $378 \mathrm{~mm}$ in 2012. The water requirements were determined for different months based on crop growth stages and climatic data.

\subsection{Water use efficiencies (WUE)}

Water use efficiency $\left(W U E_{y}, \mathrm{~kg} / \mathrm{m}^{3}\right)$ was calculated as the ratio between total fresh yield at harvest $(\mathrm{kg} / \mathrm{ha})$ and total water used $\left(\mathrm{m}^{3} / \mathrm{ha}\right)$. Water use efficiency $\left(W U E_{m}, \mathrm{~kg} / \mathrm{m}^{3}\right)$ was also calculated from marketable total yield $(\mathrm{kg} / \mathrm{ha})$ and total water use $\left(\mathrm{m}^{3} / \mathrm{ha}\right)$ and $\left(W U E_{b}, \mathrm{~kg} / \mathrm{m}^{3}\right)$ from total dry 
biomass at harvest ( $\mathrm{kg} / \mathrm{ha}$ ) and total water use $\left(\mathrm{m}^{3} / \mathrm{ha}\right.$ ) (Lovelli et al., 2007).

\subsection{Bulb weight and total yield parts}

Average bulb weight computed by weighing ten bulbs together and calculating the average. Total dry biomass was recorded as the weight of the bulb, above ground parts and roots at the time of maturity after drying at a temperature of $70^{\circ} \mathrm{C}$ in an oven to a constant weight. Harvest index is the ratio of dry bulb weight to total dry biomass yield per plant. The data set is the average of ten randomly taken plants in each experimental plot.

Total bulb yield was computed based on the weight of matured bulbs yield per plot and converted into hectare base and expressed in tones. Marketable bulb yield was determined after discarding bulbs smaller than 3 $\mathrm{cm}$ in diameter, split bulbs, neck thickness, rotten and discolored. Split bulbs percentage was determined by counting the number of split bulbs per plot and expressed in percentage in reference to the total number of normal bulbs per plot. Bulbs and leaves were harvested separately. Plant material was firstly dried at $105{ }^{\circ} \mathrm{C}$ for $30 \mathrm{~min}$, and then dried at $70{ }^{\circ} \mathrm{C}$ to constant weight. Each treatment was replicated three times.

\subsection{Onion quality}

Changes in $\mathrm{N}, \mathrm{P}$, and $\mathrm{K}$ were assessed in the experiment at the 16 treatments using 10 bulbs per replicate for each treatment. To determine the quantity of $\mathrm{K}$ in onion, the Flame Photometer instrument was used, while Spectrophotometer instrument was used to determine quantity of $\mathrm{P}$ and Gerhardt instrument was used to determine quantity of $\mathrm{N}$. Also total soluble solids (TSS) had been determined according to (AOAC 2000). The samples were tested in faculty of Science - Omar El-Mukhtar University. For grading, onion bulbs were classified into four categories on the basis of size of bulb: A, with size $>60 \mathrm{~mm}$; B, with size $60-41 \mathrm{~mm}$; C, with size 40-30 mm; D, with size $<30 \mathrm{~mm}$ under each irrigation treatment (Kumar et al, 2007).

\subsection{Statistical analysis}

Analysis of variance (ANOVA) was performed using two-way ANOVA from MSTAT software. All the treatment means were compared for any 
significant differences using the Duncan's multiple range tests at significant level of $\mathrm{P}_{0.05}$.

\section{RESULTS AND DISCUSSION}

\section{Effect of different water levels and NPK rates on total and marketable bulb yield of onion}

The bulb yield significantly $(\mathrm{P}<0.05)$ increased with increasing applied water level but different rates of NPK did not significantly affect the bulb yield. The increase in yield was mainly because of a positive association between yield and yield attributing characters like bulb diameter, bulb length and bulb weight. In 2011, significantly higher bulb yields (27.73, $26.98,25.61,23.63$ and 21.83 ton/ha) were obtained with $\mathrm{I}_{100} \mathrm{~F}_{100}, \mathrm{I}_{100} \mathrm{~F}_{75}$, $\mathrm{I}_{100} \mathrm{~F}_{50}, \mathrm{I}_{100} \mathrm{~F}_{0}$ and $\mathrm{I}_{85} \mathrm{~F}_{100}$ treatments, respectively as shown in table (2). Lower yields were observed for the $65,75 \% \mathrm{ET}_{\mathrm{c}}, 0$ and $50 \%$ NPK treatments. In 2011, even though numerically higher yield was observed with the $100 \%$ than with the $85 \% \mathrm{ET}_{\mathrm{c}}$ treatments, they were not statistically different. However, yields dropped significantly with the interaction of $65,75 \% \mathrm{ET}_{\mathrm{c}}, 0$ and $50 \% \mathrm{NPK}$ treatments. Similar results were observed for these treatments in 2012, probably, because the $100 \%$ and $85 \% \mathrm{ET}_{\mathrm{c}}$ treatments had approximately the same soil moisture conditions (Fig. 2) and crop yields were not affected. However, yields dropped significantly with the $65,75 \% \mathrm{ET}_{\mathrm{c}}, 0$ and $50 \%$ NPK treatments in both seasons.

Onion yields classified by size into small, medium, jumbo, and colossal size classes. Jumbo and colossal size onions have greater market value (Enciso et al., 2009). Water level and NPK applications significantly affected the small, medium and jumbo onion sizes but did not significantly affect the colossal onion sizes in both seasons. In the jumbo size class, higher yields were observed with $\mathrm{I}_{100} \mathrm{~F}_{100}, \mathrm{I}_{100} \mathrm{~F}_{75}$ and $\mathrm{I}_{85} \mathrm{~F}_{100}$ treatments in both seasons. This is an indication that larger onion sizes can be produced when more water is applied with higher NPK application. The water levels affected the size of the onion. These results are in agreement with the results reported by Enciso et al. (2009) who obtained higher total marketable with wetter treatments. 


\section{Table (2): Effect of different irrigation levels and NPK fertilization} rates on onion yield parameters as classified by size classes.

\begin{tabular}{|c|c|c|c|c|c|c|c|c|c|c|c|c|}
\hline \multirow{3}{*}{ Treatments } & \multicolumn{8}{|c|}{ Size class } & \multirow{2}{*}{\multicolumn{2}{|c|}{ Marketable, $\mathbf{t} / \mathbf{h a}$}} & \multirow{2}{*}{\multicolumn{2}{|c|}{ Total yield, t/ha }} \\
\hline & \multicolumn{2}{|c|}{ Small } & \multicolumn{2}{|c|}{ Med. } & \multicolumn{2}{|c|}{ Jumbo } & \multicolumn{2}{|c|}{ Colossal } & & & & \\
\hline & 2011 & 2012 & 2011 & 2012 & 2011 & 2012 & 2011 & 2012 & 2011 & 2012 & 2011 & 2012 \\
\hline $\mathbf{I}_{100} \mathbf{F}_{100}$ & $1.36^{\mathrm{b}}$ & $0.64^{\mathrm{ef}}$ & $9.18^{\mathrm{bc}}$ & $3.08^{\mathrm{ef}}$ & $13.26^{\mathrm{a}}$ & $19.80^{\mathrm{a}}$ & $2.98^{\mathrm{a}}$ & $1.93^{\mathrm{a}}$ & $25.41^{\mathrm{a}}$ & $24.81^{\mathrm{a}}$ & $27.73^{\mathrm{a}}$ & $26.18^{\mathrm{a}}$ \\
\hline $\mathbf{I}_{100} \mathbf{F}_{75}$ & $2.08^{\mathrm{ab}}$ & $1.93^{\mathrm{de}}$ & $9.20^{\mathrm{bc}}$ & $3.22^{\mathrm{ef}}$ & $13.72^{\mathrm{a}}$ & $18.57^{\mathrm{a}}$ & $1.21^{\mathrm{b}}$ & $1.69^{\mathrm{a}}$ & $24.13^{\mathrm{ab}}$ & $23.49^{\mathrm{ab}}$ & $26.98^{\mathrm{a}}$ & $25.69^{\mathrm{a}}$ \\
\hline$I_{100} F_{50}$ & $1.59^{\mathrm{b}}$ & $2.36^{\mathrm{cd}}$ & $5.85^{\mathrm{cde}}$ & $14.18^{\mathrm{a}}$ & $17.00^{\mathrm{a}}$ & $6.50^{\mathrm{c}}$ & $0.87^{\mathrm{b}}$ & $0.00^{\mathrm{b}}$ & $23.72^{\mathrm{ab}}$ & $20.68^{\text {bcd }}$ & $25.61^{\mathrm{a}}$ & $23.15^{\mathrm{a}}$ \\
\hline $\mathbf{I}_{\mathbf{1 0 0}} \mathrm{F}_{\mathbf{0}}$ & $3.18^{\mathrm{ab}}$ & $3.40^{\mathrm{bc}}$ & $6.53^{\text {cde }}$ & $11.03^{\mathrm{ab}}$ & $12.46^{\mathrm{a}}$ & $5.41^{\mathrm{c}}$ & $0.69^{\mathrm{b}}$ & $0.00^{\mathrm{b}}$ & $19.68^{\mathrm{abc}}$ & $16.44^{\text {cde }}$ & $23.63^{\mathrm{ab}}$ & $19.93^{\mathrm{ab}}$ \\
\hline $\mathbf{I}_{85} \mathbf{F}_{100}$ & $2.98^{\mathrm{ab}}$ & $0.48^{\mathrm{f}}$ & $13.86^{\mathrm{a}}$ & $8.91^{\mathrm{bc}}$ & $4.33^{\mathrm{b}}$ & $13.28^{\mathrm{b}}$ & $0.00^{\mathrm{b}}$ & $0.32^{\mathrm{b}}$ & $18.19^{\text {abcd }}$ & $22.52^{\mathrm{abc}}$ & $21.83^{\mathrm{abc}}$ & $23.68^{\mathrm{a}}$ \\
\hline $\mathbf{I}_{85} \mathbf{F}_{75}$ & $1.36^{\mathrm{b}}$ & $0.54^{\mathrm{f}}$ & $12.69^{\mathrm{ab}}$ & $9.06^{\mathrm{bc}}$ & $4.33^{\mathrm{b}}$ & $6.40^{\mathrm{c}}$ & $0.00^{\mathrm{b}}$ & $0.00^{\mathrm{b}}$ & $17.02^{\mathrm{bcd}}$ & $15.47^{\text {cde }}$ & $18.84^{\text {abcd }}$ & $16.17^{\mathrm{abc}}$ \\
\hline $\mathbf{I}_{85} \mathbf{F}_{50}$ & $6.30^{\mathrm{a}}$ & $1.42^{\mathrm{def}}$ & $5.08^{\text {cde }}$ & $7.99^{\mathrm{bcd}}$ & $2.50^{\mathrm{b}}$ & $3.01^{\mathrm{d}}$ & $0.00^{\mathrm{b}}$ & $0.00^{\mathrm{b}}$ & $7.58^{\mathrm{e}}$ & $11.00^{\text {cde }}$ & $14.16^{\mathrm{bcd}}$ & $12.53^{\mathrm{bc}}$ \\
\hline $\mathbf{I}_{85} \mathbf{F}_{0}$ & $1.32^{\mathrm{b}}$ & $1.55^{\mathrm{def}}$ & $7.93^{\mathrm{cd}}$ & $8.43^{\mathrm{bc}}$ & $4.01^{\mathrm{b}}$ & $2.60^{\mathrm{d}}$ & $0.00^{\mathrm{b}}$ & $0.00^{\mathrm{b}}$ & $11.94^{\mathrm{vde}}$ & $11.03^{\text {cde }}$ & $13.38^{\mathrm{bcd}}$ & $12.63^{\mathrm{bc}}$ \\
\hline $\mathbf{I}_{75} \mathbf{F}_{100}$ & $1.91^{\mathrm{ab}}$ & $1.92^{\mathrm{de}}$ & $7.07^{\mathrm{cd}}$ & $7.30^{\text {bcde }}$ & $4.49^{\mathrm{b}}$ & $2.31^{\mathrm{d}}$ & $0.00^{\mathrm{b}}$ & $0.00^{\mathrm{b}}$ & $11.55^{\text {cde }}$ & $9.61^{\text {cde }}$ & $13.64^{\text {bcd }}$ & $11.78^{\mathrm{bc}}$ \\
\hline $\mathbf{I}_{75} \mathbf{F}_{75}$ & $1.32^{\mathrm{b}}$ & $1.64^{\mathrm{def}}$ & $7.29^{\mathrm{cd}}$ & $6.30^{\text {cdef }}$ & $4.09^{\mathrm{b}}$ & $2.74^{\mathrm{d}}$ & $0.56^{\mathrm{b}}$ & $0.00^{\mathrm{b}}$ & $11.94^{\text {cde }}$ & $9.04^{\text {cde }}$ & $13.73^{\mathrm{bcd}}$ & $10.76^{\mathrm{bc}}$ \\
\hline $\mathbf{I}_{75} \mathbf{F}_{50}$ & $1.38^{\mathrm{b}}$ & $1.58^{\mathrm{def}}$ & $8.52^{\text {bcd }}$ & $5.01^{\text {cdef }}$ & $1.52^{\mathrm{b}}$ & $2.11^{\mathrm{d}}$ & $0.00^{\mathrm{b}}$ & $0.00^{\mathrm{b}}$ & $10.04^{\mathrm{de}}$ & $7.13^{\text {cde }}$ & $11.61^{\mathrm{cd}}$ & $8.83^{\mathrm{c}}$ \\
\hline $\mathbf{I}_{75} \mathbf{F}_{0}$ & $3.24^{\mathrm{ab}}$ & $6.79^{\mathrm{a}}$ & $5.04^{\text {cde }}$ & $3.06^{\mathrm{ef}}$ & $2.37^{\mathrm{b}}$ & $1.36^{\mathrm{d}}$ & $0.00^{\mathrm{b}}$ & $0.00^{\mathrm{b}}$ & $7.42^{\mathrm{e}}$ & $4.42^{\text {cde }}$ & $10.73^{d}$ & $11.27^{\mathrm{bc}}$ \\
\hline $\mathbf{I}_{65} \mathbf{F}_{100}$ & $4.77^{\mathrm{ab}}$ & $3.55^{\mathrm{bc}}$ & $5.57^{\text {cde }}$ & $6.01^{\text {cdef }}$ & $2.34^{\mathrm{b}}$ & $1.09^{\mathrm{d}}$ & $0.00^{\mathrm{b}}$ & $0.00^{\mathrm{b}}$ & $7.91^{\mathrm{e}}$ & $7.11^{\text {bcde }}$ & $12.82^{\mathrm{bcd}}$ & $10.80^{\mathrm{bc}}$ \\
\hline $\mathbf{I}_{65} \mathbf{F}_{75}$ & $3.00^{\mathrm{ab}}$ & $3.65^{\mathrm{bc}}$ & $4.39^{\mathrm{de}}$ & $2.88^{\mathrm{f}}$ & $1.88^{\mathrm{b}}$ & $1.54^{\mathrm{d}}$ & $0.00^{\mathrm{b}}$ & $0.00^{\mathrm{b}}$ & $6.26^{\mathrm{e}}$ & $4.42^{\text {cde }}$ & $9.39^{\mathrm{d}}$ & $8.13^{\mathrm{c}}$ \\
\hline $\mathbf{I}_{65} \mathbf{F}_{50}$ & $4.88^{\mathrm{ab}}$ & $3.42^{\mathrm{bc}}$ & $2.36^{\mathrm{e}}$ & $3.99^{\mathrm{def}}$ & $1.76^{\mathrm{b}}$ & $1.14^{\mathrm{d}}$ & $0.00^{\mathrm{b}}$ & $0.00^{\mathrm{b}}$ & $4.12^{\mathrm{e}}$ & $5.14^{\mathrm{de}}$ & $9.06^{\mathrm{d}}$ & $8.64^{\mathrm{c}}$ \\
\hline$I_{65} \mathbf{F}_{0}$ & $0.82^{\mathrm{b}}$ & $3.87^{\mathrm{b}}$ & $5.40^{\text {cde }}$ & $2.97^{\mathrm{f}}$ & $2.26^{\mathrm{b}}$ & $2.08^{\mathrm{d}}$ & $0.00^{\mathrm{b}}$ & $0.00^{\mathrm{b}}$ & $7.67^{\mathrm{e}}$ & $5.05^{\mathrm{e}}$ & $8.52^{\mathrm{d}}$ & $9.07^{\mathrm{c}}$ \\
\hline F-test & & & & & & & & & & & & \\
\hline Irrigation & NS & $*$ & $*$ & $*$ & $*$ & $*$ & $*$ & $*$ & $*$ & * & $*$ & $*$ \\
\hline Fertilization & NS & $*$ & NS & NS & NS & $*$ & NS & NS & $*$ & NS & NS & NS \\
\hline Irri. * Fert. & * & $*$ & * & $*$ & $*$ & $*$ & * & * & $*$ & * & * & $*$ \\
\hline
\end{tabular}

NS and *: Non-significant, significant at $\mathrm{P}>0.05$, respectively. Means with the same treatment and column sharing the same letters are not significantly different at $\mathrm{P}<0.05$.

The relationships of yield to different water levels and NPK rates were studied. The greatest effect of increasing applied water was the curvilinear rise in total yield and marketable yield in both seasons (Figure 1). There were parabolic correlations between total yield and marketable yield under different water levels and NPK fertilization treatments. 
2011
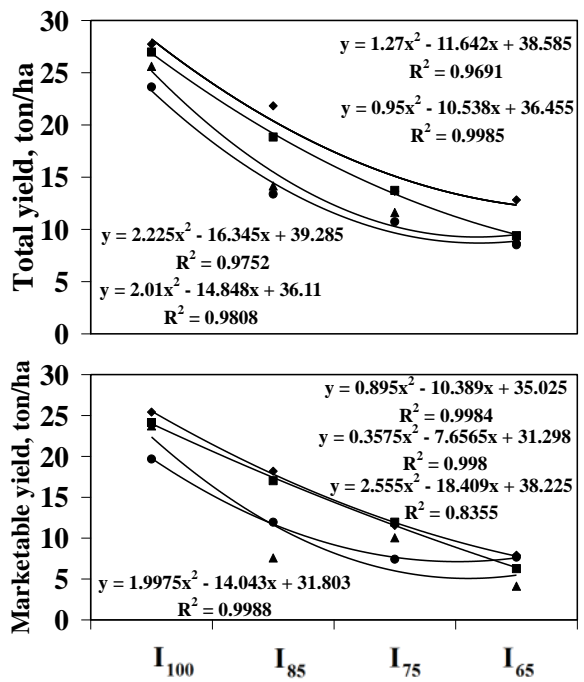

Water treatments
2012
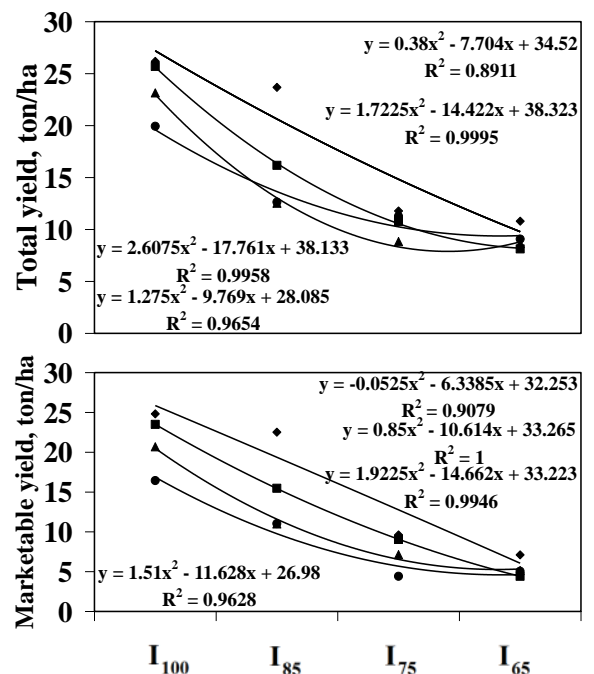

Water treatments

- NPK100 — NPK75 $\triangle$ NPK50 • NPK0

Figure (1): Correlations between total yield, marketable yield and water levels at different NPK rates in seasons 2011 and 2012.

The results showed that the interaction between water level and NPK application had the greater effect of increasing total yield and marketable yield. As shown in table (2), the first five treatments had the maximum total yield and marketable yield without significant differences although there are some differences that may be due to the different soil content of nutrients found, which may vary from one site to another. The total yield and marketable yield reduction due to water and fertilizer stress ranged from $2.7 \%$ to $21.28 \%$ and from $5.04 \%$ to $28.41 \%$, respectively in 2011 and from $1.87 \%$ to $23.87 \%$ and from $5.32 \%$ to $33.74 \%$, respectively in 2012. The maximum yield and marketable yield reduction was obtained under $\mathrm{I}_{65} \mathrm{~F}_{50}$ and $\mathrm{I}_{65} \mathrm{~F}_{0}$ treatments, respectively in 2011 and under the same treatment $\mathrm{I}_{65} \mathrm{~F}_{75}$ in 2012, while the lowest yield and marketable yield reduction was recorded under the same treatment $\mathrm{I}_{100} \mathrm{~F}_{75}$ in both years. Yield and marketable yield over all the treatments of this study were not significantly different between the $\mathrm{I}_{100} \mathrm{~F}_{100}, \mathrm{I}_{100} \mathrm{~F}_{75}$ and $\mathrm{I}_{85} \mathrm{~F}_{100}$ treatments in 2011 and 2012 (Table 2). Lower yield and marketable yield were observed 
for the 65, $75 \% \mathrm{ETc}, 0$, and 50\% NPK treatments. Even though numerically higher yield parameters were observed with the $100 \%$ than with the $85 \%$ ETc treatments, they were not statistically different. Similar results were observed for these treatments, because the $100 \%$ and $85 \%$ ETc treatments kept same water moisture content at first layers and onions have shallower root systems and onion yield and marketable yield were not affected. In conclusion, Pegue onion plant showed differential response to different water applied with different rates of NPK. Best response, as observed by the yield and marketable yield of Pegue onion, was obtained when planting with treatment $\mathrm{I}_{100} \mathrm{~F}_{100}, \mathrm{I}_{100} \mathrm{~F}_{75}$ and $\mathrm{I}_{85} \mathrm{~F}_{100}$.

\section{Effect of different water levels and NPK applications on dry bulb yield, total dry biomass and harvest index of onion}

The increase in applied water level significantly decreased the percent of dry matter in the onion bulb but the increase in NPK rates increased significantly the percent of dry matter in the onion bulb in both years. On the other hand, as shown in table (3) under the same water level, the decrease of NPK rate decreased the dry bulb yield and total dry biomass. The interaction between different water levels and NPK rates showed that $\mathrm{I}_{100} \mathrm{~F}_{100}, \mathrm{I}_{100} \mathrm{~F}_{75}, \mathrm{I}_{100} \mathrm{~F}_{50}$, and $\mathrm{I}_{75} \mathrm{~F}_{100}$ treatments recorded the significantly highest dry matter production of $2.175,1.770,1.548$, and 1.611 ton/ha, respectively in 2011 and recorded the significantly highest dry matter production of $1.749,1.674,1.640$, and 1.692 ton/ha, respectively in 2012 . The increase in dry matter production in mentioned treatments was mainly because of the increase in yield and bulb weight in these treatments. Table (3) shows that increasing the applied water increased significantly the total dry biomass while NPK rates did not. The interaction between different water levels and NPK rates showed that $100,85 \% \mathrm{ET}_{\mathrm{c}}$ treatments recorded the highest total dry biomass in the two seasons. In case of harvest index neither water levels nor NPK rates had significant effect but the interaction between water levels and NPK rates had significant effect on harvest index (table 3). The results showed that $\mathrm{I}_{100} \mathrm{~F}_{100}$, and $\mathrm{I}_{100} \mathrm{~F}_{75}$ treatments recorded the significantly highest harvest index of 0.84 and 0.78 , respectively in 2011 and $\mathrm{I}_{100} \mathrm{~F}_{100}$, and $\mathrm{I}_{85} \mathrm{~F}_{100}$ treatments recorded the significantly highest harvest index of 0.79 and 0.85 , respectively in 2012 . 
Table (3): The influence of different applied water and different rates of NPK on dry bulb yield, total dry biomass and harvest index of onion.

\begin{tabular}{|c|c|c|c|c|c|c|}
\hline \multirow[t]{2}{*}{ Treatments } & \multicolumn{2}{|c|}{$\begin{array}{l}\text { Dry bulb yield, } \\
\text { ton/ha }\end{array}$} & \multicolumn{2}{|c|}{$\begin{array}{c}\text { Total dry biomass, } \\
\text { ton/ha }\end{array}$} & \multicolumn{2}{|c|}{ Harvest index } \\
\hline & 2011 & 2012 & 2011 & 2012 & 2011 & 2012 \\
\hline $\mathbf{I}_{\mathbf{1 0 0}} \mathbf{F}_{\mathbf{1 0 0}}$ & $2.175^{\mathrm{a}}$ & $1.749^{\mathrm{a}}$ & $2.592^{\mathrm{a}}$ & $2.202^{\mathrm{abc}}$ & $0.84^{\mathrm{a}}$ & $0.79^{\mathrm{ab}}$ \\
\hline $\mathbf{I}_{100} \mathbf{F}_{75}$ & $1.770^{\mathrm{ab}}$ & $1.674^{\mathrm{abc}}$ & $2.271^{\mathrm{ab}}$ & $2.480^{\mathrm{ab}}$ & $0.78^{\mathrm{a}}$ & $0.68^{\mathrm{ab}}$ \\
\hline $\mathbf{I}_{100} \mathbf{F}_{50}$ & $1.548^{\mathrm{abc}}$ & $1.640^{\mathrm{abc}}$ & $2.100^{\mathrm{abc}}$ & $2.446^{\mathrm{ab}}$ & $0.74^{\mathrm{a}}$ & $0.67^{\mathrm{ab}}$ \\
\hline $\mathbf{I}_{100} \mathbf{F}_{0}$ & $1.296^{\mathrm{abc}}$ & $1.563^{\mathrm{abcd}}$ & $1.903^{\mathrm{abc}}$ & $2.221^{\mathrm{abc}}$ & $0.68^{\mathrm{a}}$ & $0.70^{\mathrm{ab}}$ \\
\hline $\mathbf{I}_{\mathbf{8 5}} \mathbf{F}_{\mathbf{1 0 0}}$ & $1.504^{\mathrm{abc}}$ & $1.609^{\mathrm{abcd}}$ & $2.623^{\mathrm{a}}$ & $1.901^{\mathrm{abc}}$ & $0.57^{\mathrm{a}}$ & $0.85^{\mathrm{a}}$ \\
\hline $\mathbf{I}_{85} \mathbf{F}_{75}$ & $1.173^{\mathrm{bc}}$ & $1.096^{\mathrm{abcd}}$ & $1.706^{\mathrm{bc}}$ & $2.049^{\mathrm{abc}}$ & $0.69^{a}$ & $0.53^{b c}$ \\
\hline $\mathbf{I}_{85} \mathbf{F}_{50}$ & $1.506^{\mathrm{abc}}$ & $1.521^{\mathrm{abcd}}$ & $2.031^{\mathrm{abc}}$ & $2.514^{\mathrm{ab}}$ & $0.74^{\mathrm{a}}$ & $0.61^{\mathrm{abc}}$ \\
\hline $\mathbf{I}_{85} \mathbf{F}_{0}$ & $1.385^{\mathrm{abc}}$ & $1.156^{\mathrm{abcd}}$ & $1.949^{\mathrm{abc}}$ & $2.098^{\mathrm{abc}}$ & $0.71^{\mathrm{a}}$ & $0.55^{\mathrm{bc}}$ \\
\hline $\mathbf{I}_{\mathbf{7 5}} \mathbf{F}_{100}$ & $1.611^{\mathrm{abc}}$ & $1.692^{\mathrm{ab}}$ & $2.162^{\mathrm{ab}}$ & $2.377^{\mathrm{abc}}$ & $0.75^{\mathrm{a}}$ & $0.62^{\mathrm{abc}}$ \\
\hline $\mathbf{I}_{\mathbf{7 5}} \mathbf{F}_{\mathbf{7 5}}$ & $1.522^{\mathrm{abc}}$ & $1.504^{\mathrm{abcd}}$ & $2.034^{\mathrm{abc}}$ & $2.548^{\mathrm{a}}$ & $0.75^{\mathrm{a}}$ & $0.59^{\mathrm{abc}}$ \\
\hline $\mathbf{I}_{\mathbf{7 5}} \mathbf{F}_{\mathbf{5 0}}$ & $0.909^{\mathrm{bc}}$ & $0.953^{\mathrm{abcd}}$ & $1.615^{\mathrm{bc}}$ & $2.040^{\mathrm{abc}}$ & $0.56^{\mathrm{a}}$ & $0.47^{\mathrm{c}}$ \\
\hline $\mathbf{I}_{\mathbf{7 5}} \mathbf{F}_{\mathbf{0}}$ & $0.888^{\mathrm{bc}}$ & $0.915^{\mathrm{bcd}}$ & $1.613^{\mathrm{bc}}$ & $1.974^{\mathrm{abc}}$ & $0.55^{\mathrm{a}}$ & $0.46^{\mathrm{c}}$ \\
\hline$I_{65} F_{100}$ & $1.174^{\mathrm{bc}}$ & $1.170^{\text {abcd }}$ & $1.660^{\mathrm{bc}}$ & $1.755^{\mathrm{abc}}$ & $0.71^{\mathrm{a}}$ & $0.67^{\mathrm{ab}}$ \\
\hline $\mathbf{I}_{65} \mathbf{F}_{75}$ & $1.069^{\mathrm{bc}}$ & $0.931^{\mathrm{bcd}}$ & $1.501^{\mathrm{bc}}$ & $1.722^{\mathrm{abc}}$ & $0.71^{\mathrm{a}}$ & $0.54^{\mathrm{bc}}$ \\
\hline$I_{65} F_{50}$ & $0.994^{\mathrm{bc}}$ & $0.879^{\mathrm{cd}}$ & $1.501^{\mathrm{bc}}$ & $1.641^{\mathrm{bc}}$ & $0.66^{\mathrm{a}}$ & $0.54^{\mathrm{bc}}$ \\
\hline $\mathbf{I}_{65} \mathbf{F}_{\mathbf{0}}$ & $0.812^{\mathrm{c}}$ & $0.824^{\mathrm{d}}$ & $1.334^{\mathrm{c}}$ & $1.510^{\mathrm{c}}$ & $0.61^{\mathrm{a}}$ & $0.55^{\mathrm{bc}}$ \\
\hline $\begin{array}{l}\text { F-test } \\
\text { Irrigation }\end{array}$ & $*$ & $*$ & $*$ & NS & NS & NS \\
\hline Fertilization & NS & NS & NS & NS & NS & $*$ \\
\hline Irri. * Fert. & $*$ & $*$ & $*$ & $*$ & NS & $*$ \\
\hline
\end{tabular}

The relationships of dry bulb yield and total dry biomass to different water levels and NPK rates were studied. The greatest effect of increasing applied water was the curvilinear rise in dry bulb yield and total dry biomass in both seasons (Figure 2). There were parabolic correlations between dry bulb, and biomass yield under different water level and NPK fertilization treatments. 
2011
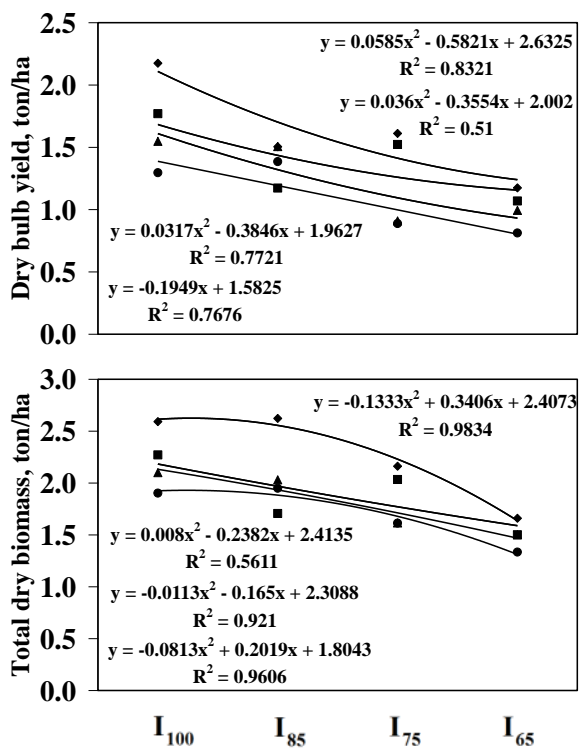

Water treatments
2012
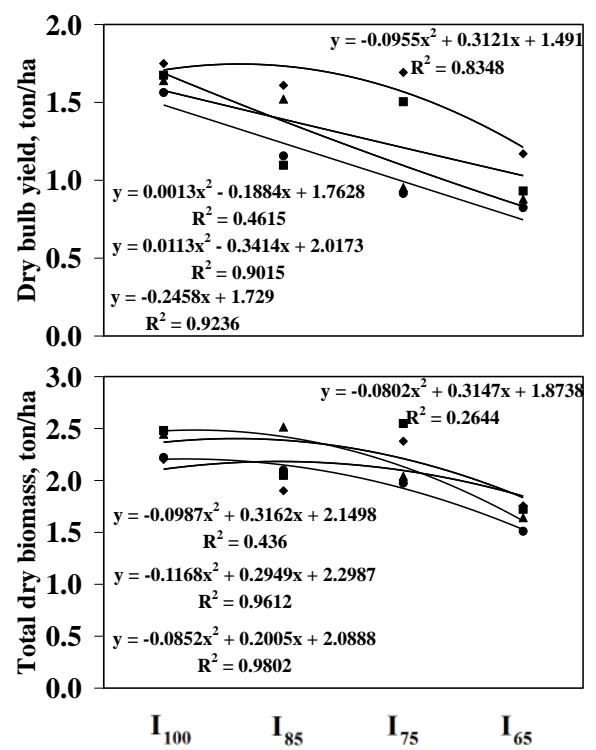

Water treatments

- NPK100 — NPK75 $\triangle$ NPK50 • NPK0

Figure (2): Correlations between dry bulb yield, total dry biomass and water levels at different NPK rates in seasons of 2011 and 2012.

\section{Water use efficiencies of onion}

There was significant effect of irrigation levels on $\mathrm{WUE}_{\mathrm{y}}$ and $\mathrm{WUE}_{\mathrm{m}}$ of onion (table 4) but there was no significant effect of NPK rates on $\mathrm{WUE}_{\mathrm{y}}$ and $W_{\mathrm{m}}$ in 2011 while 2012, there was significant effect of NPK rates on $\mathrm{WUE}_{\mathrm{m}}$. The maximum $\mathrm{WUE}_{\mathrm{y}}$ and $\mathrm{WUE}_{\mathrm{m}}$ values were observed with 85 and $100 \% \mathrm{ET}_{\mathrm{c}}$ while the minimum values were observed with 65 and 75 $\% \mathrm{ET}_{\mathrm{c}}$ in the two years. As shown in table (4), when the water level decreased from $100 \% \mathrm{ET}_{\mathrm{c}}$ to $85 \% \mathrm{ET}_{\mathfrak{c}}$, in treatment $\mathrm{I}_{85} \mathrm{~F}_{100}$ was non significantly decreased the $\mathrm{WUE}_{\mathrm{y}}$ and $\mathrm{WUE}_{\mathrm{m}}$ by about 7.93 and $16.41 \%$ when compared to treatment $\mathrm{I}_{100} \mathrm{~F}_{100}$, respectively in 2011 , while in treatment $\mathrm{I}_{85} \mathrm{~F}_{100}$ were non significantly increased the $\mathrm{WUE}_{\mathrm{y}}$ and $\mathrm{WUE}_{\mathrm{m}}$ by about 6.44 and $6.14 \%$ when compared to treatment $\mathrm{I}_{100} \mathrm{~F}_{100}$, respectively in 2012. Also as shown in table (4), when the NPK rate decreased from 100 $\%$ to $75 \%$, in treatment $\mathrm{I}_{100} \mathrm{~F}_{75}$ the $\mathrm{WUE}_{\mathrm{y}}$ and $\mathrm{WUE}_{\mathrm{m}}$ were non significantly decreased by about 2.85 and $5.1 \%$ when compared to 
treatment $\mathrm{I}_{100} \mathrm{~F}_{100}$, respectively in 2011 , while in treatment $\mathrm{I}_{100} \mathrm{~F}_{75}$ the $\mathrm{WUE}_{\mathrm{y}}$ and $\mathrm{WUE}_{\mathrm{m}}$ were non significantly decreased by about 2 and $5.45 \%$ when compared to treatment $\mathrm{I}_{100} \mathrm{~F}_{100}$, respectively in 2012. Therefore, the same yield can be obtained without significant effect when decreasing the water irrigation by about $15 \%$ or by decreasing NPK fertilization by about $25 \%$. As shown in table (4), the results showed that there is no significant effect for irrigation levels, NPK rates, or interaction between irrigation levels and NPK rates on $\mathrm{WUE}_{\mathrm{d}}$ for all treatments in the two years.

Table (4): The influence of different applied water and different rates of NPK on WUE,$W U E_{m}$, and WUE ${ }_{d}$ of onion.

\begin{tabular}{|c|c|c|c|c|c|c|}
\hline \multirow{2}{*}{ Treat. } & \multicolumn{2}{|c|}{ WUE $_{y}, \mathbf{k g} / \mathrm{m}^{3}$} & \multicolumn{2}{|c|}{$\mathrm{WUE}_{\mathrm{m}}, \mathrm{kg} / \mathrm{m}^{3}$} & \multicolumn{2}{|c|}{$W_{U} E_{d}, \mathrm{~kg} / \mathrm{m}^{3}$} \\
\hline & 2011 & 2012 & 2011 & 2012 & 2011 & 2012 \\
\hline $\mathbf{I}_{100} \mathbf{F}_{100}$ & $4.92^{\mathrm{a}}$ & $4.50^{\mathrm{a}}$ & $4.51^{\mathrm{a}}$ & $4.40^{\mathrm{a}}$ & $0.38^{\mathrm{a}}$ & $0.31^{\mathrm{a}}$ \\
\hline $\mathbf{I}_{100} \mathbf{F}_{75}$ & $4.78^{\mathrm{ab}}$ & $4.41^{\mathrm{ab}}$ & $4.28^{\mathrm{a}}$ & $4.16^{\mathrm{a}}$ & $0.31^{\mathrm{a}}$ & $0.30^{\mathrm{a}}$ \\
\hline$I_{100} F_{50}$ & $4.54^{\mathrm{abc}}$ & $3.98^{\mathrm{abc}}$ & $4.21^{\mathrm{ab}}$ & $3.67^{\mathrm{ab}}$ & $0.27^{\mathrm{a}}$ & $0.29^{\mathrm{a}}$ \\
\hline $\mathbf{I}_{100} \mathbf{F}_{0}$ & $4.19^{\text {abcde }}$ & $3.42^{\mathrm{abcd}}$ & $3.49^{\mathrm{abcd}}$ & $2.91^{\mathrm{abc}}$ & $0.23^{\mathrm{a}}$ & $0.28^{\mathrm{a}}$ \\
\hline $\mathbf{I}_{85} \mathbf{F}_{100}$ & $4.53^{\mathrm{abcd}}$ & $4.79^{\mathrm{a}}$ & $3.77^{\mathrm{abc}}$ & $4.67^{\mathrm{a}}$ & $0.31^{\mathrm{a}}$ & $0.33^{\mathrm{a}}$ \\
\hline $\mathbf{I}_{85} \mathbf{F}_{75}$ & $3.91^{\text {abcde }}$ & $3.27^{\mathrm{abcd}}$ & $3.53^{\mathrm{abcd}}$ & $3.21^{\mathrm{abc}}$ & $0.24^{\mathrm{a}}$ & $0.23^{\mathrm{a}}$ \\
\hline$I_{85} F_{50}$ & $2.94^{\text {bcde }}$ & $2.54^{\mathrm{bcd}}$ & $1.57^{\mathrm{ef}}$ & $2.28^{\mathrm{bcd}}$ & $0.31^{\mathrm{a}}$ & $0.32^{\mathrm{a}}$ \\
\hline $\mathbf{I}_{85} \mathbf{F}_{0}$ & $2.78^{\text {cde }}$ & $2.56^{\mathrm{bcd}}$ & $2.48^{\text {cdef }}$ & $2.29^{\mathrm{bcd}}$ & $0.29^{\mathrm{a}}$ & $0.24^{\mathrm{a}}$ \\
\hline $\mathbf{I}_{75} \mathbf{F}_{100}$ & $3.22^{\text {abcde }}$ & $2.70^{\mathrm{bcd}}$ & $2.73^{\text {cdef }}$ & $2.27^{\mathrm{bcd}}$ & $0.38^{\mathrm{a}}$ & $0.40^{\mathrm{a}}$ \\
\hline $\mathbf{I}_{75} \mathbf{F}_{75}$ & $3.25^{\text {abcde }}$ & $2.47^{\mathrm{bcd}}$ & $2.82^{\text {bcde }}$ & $2.14^{\mathrm{cd}}$ & $0.36^{\mathrm{a}}$ & $0.36^{\mathrm{a}}$ \\
\hline$I_{75} F_{50}$ & $2.74^{\text {cde }}$ & $2.03^{\mathrm{d}}$ & $2.37^{\text {cdef }}$ & $1.69^{\mathrm{cd}}$ & $0.21^{\mathrm{a}}$ & $0.23^{\mathrm{a}}$ \\
\hline $\mathbf{I}_{75} \mathbf{F}_{0}$ & $2.54^{\mathrm{de}}$ & $2.58^{\mathrm{bcd}}$ & $1.75^{\mathrm{ef}}$ & $1.04^{\mathrm{d}}$ & $0.21^{\mathrm{a}}$ & $0.22^{\mathrm{a}}$ \\
\hline$I_{65} F_{100}$ & $3.48^{\text {abcde }}$ & $2.86^{\mathrm{abcd}}$ & $2.15^{\text {def }}$ & $1.93^{\mathrm{cd}}$ & $0.32^{\mathrm{a}}$ & $0.32^{\mathrm{a}}$ \\
\hline$I_{65} F_{75}$ & $2.55^{\mathrm{de}}$ & $2.15^{\mathrm{d}}$ & $1.70^{\mathrm{ef}}$ & $1.20^{\mathrm{d}}$ & $0.29^{\mathrm{a}}$ & $0.25^{\mathrm{a}}$ \\
\hline$I_{65} F_{50}$ & $2.46^{\mathrm{de}}$ & $2.29^{\mathrm{cd}}$ & $1.12^{\mathrm{e}}$ & $1.40^{\mathrm{d}}$ & $0.27^{\mathrm{a}}$ & $0.24^{\mathrm{a}}$ \\
\hline$I_{65} F_{0}$ & $2.32^{\mathrm{e}}$ & $2.40^{\mathrm{bcd}}$ & $1.08^{\mathrm{def}}$ & $1.37^{\mathrm{d}}$ & $0.22^{\mathrm{a}}$ & $0.22^{\mathrm{a}}$ \\
\hline F-test & & & & & & \\
\hline Irrigation & $*$ & $*$ & $*$ & $*$ & NS & NS \\
\hline Fertilization & NS & NS & NS & $*$ & NS & NS \\
\hline Irri. * Fert. & & & 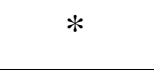 & $*$ & NS & NS \\
\hline
\end{tabular}


The relationships of $\mathrm{WUE}_{\mathrm{y}}, \mathrm{WUE}_{\mathrm{m}}$ and $\mathrm{WUE}_{\mathrm{d}}$ to different water levels and NPK rates were studied. The greatest effect of increasing applied water was the curvilinear rise in $\mathrm{WUE}_{\mathrm{y}}, \mathrm{WUE}_{\mathrm{m}}$ and $\mathrm{WUE}_{\mathrm{d}}$ in both seasons (Figure 3). There were parabolic correlations between $\mathrm{WUE}_{\mathrm{y}}, \mathrm{WUE}_{\mathrm{m}}$ and WUE $_{\mathrm{d}}$ under different water level and NPK fertilization treatments.

2011
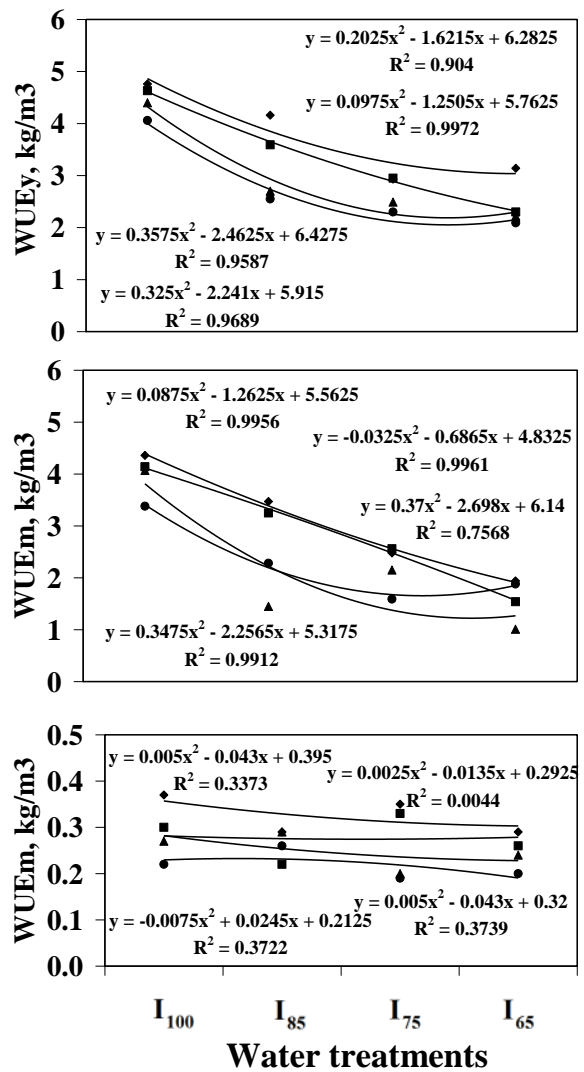

2012
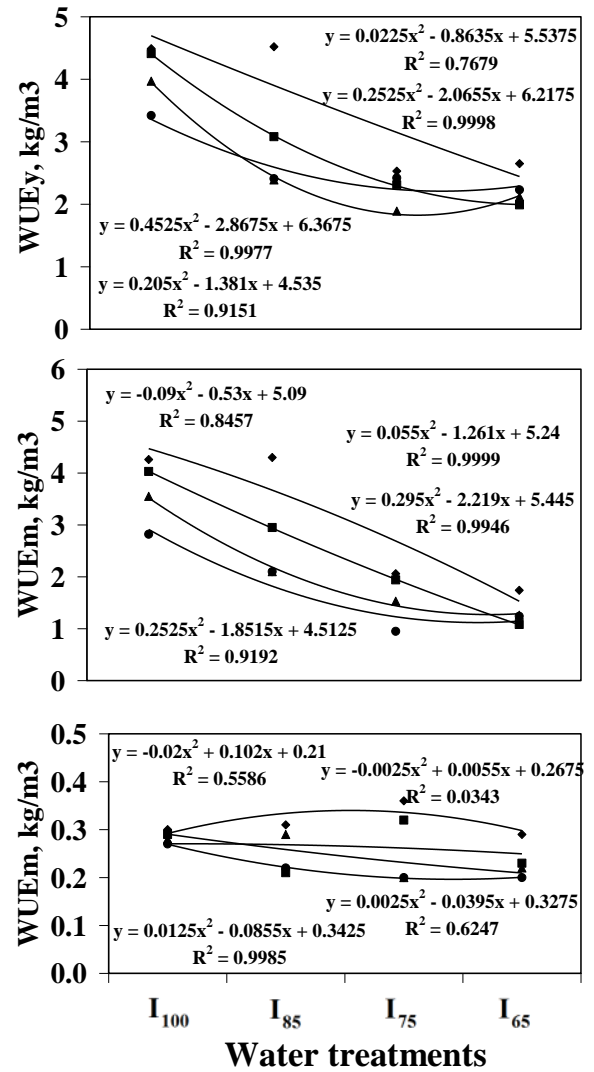

- NPK100 — NPK75 $\triangle$ NPK50 • NPK0

Figure (3): Correlations between $\mathrm{WUE}_{\mathrm{y}}, \mathrm{WUE}_{\mathrm{m}}, \mathrm{WUE}_{\mathrm{d}}$ and water levels at different NPK rates in seasons 2011 and 2012.

The highest values of $\mathrm{WUE}_{\mathrm{y}}$ and $\mathrm{WUE}_{\mathrm{m}}$ increased with water level, where its maximum values did not correspond to irrigation treatment receiving minimum water supply $\left(65 \% \mathrm{ET}_{\mathrm{c}}\right.$ ), since severe soil water deficit induced high production losses due to very small bulbs less than $30 \mathrm{~mm}$ in diameter. Indeed, it is possible to save water improving its use efficiency in 
processing onion but water should be applied to the crop throughout the whole growing season, even at a low rate $\left(85 \% \mathrm{ET}_{\mathrm{c}}\right)$, to achieve adequate bulb yield, minimizing bulb losses and maintaining high bulb quality levels. This is in agreement with previous findings in tomato cultivated under a wide range of deficit irrigation treatments (Favati et al., 2009; Ozbahce and Tari, 2010).

\section{Effect of different water levels and NPK fertilization application on} TSS, N, $P$, and $K$ content in bulb

As shown in Table (5) TSS percent of onion bulb increased significantly (P $\leq 0.05$ ) with decreasing applied water level and with increasing NPK rate. This quality parameter is greater with 65 and $75 \% \mathrm{ET}_{\mathrm{c}}, 75$ and $100 \%$ NPK in the two years compared to 85, $100 \% \mathrm{ET}_{\mathrm{c}}, 0$, and $50 \%$ NPK treatments. Considering the combination of applied water levels and NPK applications treatments, the data showed that the higher significant increase was found with $\mathrm{I}_{65} \mathrm{~F}_{100}(5.81 \%)$ in 2011 and was found with $\mathrm{I}_{75} \mathrm{~F}_{100}(6.91 \%)$ in 2012, while the minimum significant increase was found with $\mathrm{I}_{100} \mathrm{~F}_{0}$ (0.52 and $0.30 \%$ ) in both 2011 and 2012, respectively. As to the nitrogen $(\mathrm{N})$, the effect of applied water level and NPK application on N content is presented in Table (5). This quality parameter increased significantly $(\mathrm{P} \leq$ 0.05 ) in the more deficit (65 and $75 \%$ of $\mathrm{ET}_{\mathrm{c}}$ ) compared to the higher applied water treatments (85 and $100 \%$ of $\mathrm{ET}_{\mathrm{c}}$ ). Also, $\mathrm{N}$ percentage increased significantly $(\mathrm{P} \leq 0.05)$ in the higher rates of NPK (75 and $100 \%$ of NPK) compared to the low application rates of NPK treatments ( 0 and $50 \%$ of NPK). The interaction between applied water levels and NPK application rates showed that the maximum significant increase was found with $\mathrm{I}_{65} \mathrm{~F}_{100}$ (5.98 and $6.53 \%$ ) in both 2011 and 2012, respectively, while the minimum significant increase was found with $\mathrm{I}_{100} \mathrm{~F}_{0}(0.89$ and $0.16 \%)$ in both 2011 and 2012, respectively. Similar trend was observed with phosphor $(\mathrm{P})$ and potassium $(\mathrm{K})$ percentage. $\mathrm{P}$ and $\mathrm{K}$ increased significantly $(\mathrm{P} \leq 0.05)$ in the more deficit ( 65 and $75 \%$ of $\mathrm{ET}_{\mathrm{c}}$ ) compared to the higher applied water ( 85 and $100 \%$ of $\mathrm{ET}_{\mathrm{c}}$ ) treatments. While, $\mathrm{P}$ and $K$ percentages increased significantly $(\mathrm{P} \leq 0.05)$ in the higher rates of NPK (75 and $100 \%$ of NPK) compared to the low application rates of NPK 
treatments ( 0 and $50 \%$ of NPK). The interaction between applied water levels and NPK application rates showed that the maximum P percentage significantly increased with treatment $\mathrm{I}_{65} \mathrm{~F}_{100}(0.456$ and $0.397 \%)$ in both 2011 and 2012, respectively, while the minimum significant increase was found with $\mathrm{I}_{100} \mathrm{~F}_{0}(0.017$ and $0.037 \%$ ) in both 2011 and 2012, respectively. Also, the maximum $\mathrm{K}$ percentage significantly increased with treatment $\mathrm{I}_{65} \mathrm{~F}_{100}(0.427$ and $0.340 \%)$ in both 2011 and 2012, respectively, while the minimum significant increase was found with $\mathrm{I}_{100} \mathrm{~F}_{0}(0.057$ and $0.080 \%)$ in both 2011 and 2012, respectively.

Table (5): The influence of different applied water and different rates of NPK application on TSS, N, P, and $K$ content of onion.

\begin{tabular}{|c|c|c|c|c|c|c|c|c|}
\hline \multirow{2}{*}{ Treat. } & \multicolumn{2}{|c|}{ TSS, \% } & \multicolumn{2}{|c|}{$\mathrm{N}, \%$} & \multicolumn{2}{|c|}{$\mathbf{P}, \%$} & \multicolumn{2}{|c|}{$\mathbf{K}, \%$} \\
\hline & 2011 & 2012 & 2011 & 2012 & 2011 & 2012 & 2011 & 2012 \\
\hline $\mathbf{I}_{100} \mathrm{~F}_{100}$ & $4.81^{\mathrm{abc}}$ & $5.07^{\mathrm{abc}}$ & $4.93^{\mathrm{ab}}$ & $5.33^{\mathrm{ab}}$ & $0.27^{\mathrm{bc}}$ & $0.17^{\text {cde }}$ & $0.25^{\mathrm{bc}}$ & $0.30^{\mathrm{ab}}$ \\
\hline $\mathbf{I}_{100} \mathrm{~F}_{75}$ & $3.35^{\text {bcde }}$ & $4.39^{\mathrm{abcd}}$ & $2.17^{\text {cde }}$ & $2.56^{\mathrm{cd}}$ & $0.24^{\text {bcd }}$ & $0.13^{\text {cde }}$ & $0.11^{\mathrm{d}}$ & $0.17^{\text {bcd }}$ \\
\hline $\mathbf{I}_{100} \mathbf{F}_{50}$ & $1.79^{\mathrm{ef}}$ & $2.97^{\text {bcde }}$ & $2.25^{\text {cde }}$ & $1.46^{\mathrm{cde}}$ & $0.04^{\mathrm{e}}$ & $0.04^{\mathrm{e}}$ & $0.08^{\mathrm{d}}$ & $0.14^{\mathrm{cd}}$ \\
\hline $\mathbf{I}_{100} \mathbf{F}_{0}$ & $0.52^{\mathrm{f}}$ & $0.30^{\mathrm{e}}$ & $0.89^{\mathrm{e}}$ & $0.16^{\mathrm{e}}$ & $0.02^{\mathrm{e}}$ & $0.04^{\mathrm{e}}$ & $0.057^{\mathrm{d}}$ & $0.08^{\mathrm{d}}$ \\
\hline$I_{85} F_{100}$ & $5.56^{\mathrm{ab}}$ & $6.81^{\mathrm{a}}$ & $4.94^{\mathrm{ab}}$ & $5.95^{\mathrm{a}}$ & $0.34^{\mathrm{ab}}$ & $0.18^{\mathrm{cd}}$ & $0.27^{\mathrm{b}}$ & $0.30^{\mathrm{ab}}$ \\
\hline $\mathbf{I}_{85} \mathbf{F}_{75}$ & $3.68^{\text {abcde }}$ & $5.14^{\mathrm{abc}}$ & $2.47^{\text {cde }}$ & $2.55^{\mathrm{cd}}$ & $0.24^{\mathrm{bcd}}$ & $0.17^{\text {cde }}$ & $0.13^{d}$ & $0.16^{\mathrm{bcd}}$ \\
\hline$I_{85} F_{50}$ & $3.24^{\text {bcde }}$ & $2.96^{\text {bcde }}$ & $2.16^{\mathrm{cde}}$ & $1.48^{\mathrm{cde}}$ & $0.10^{\mathrm{cd}}$ & $0.13^{\text {cde }}$ & $0.10^{\mathrm{d}}$ & $0.14^{\mathrm{cd}}$ \\
\hline$I_{85} F_{0}$ & $2.39^{\mathrm{def}}$ & $1.18^{\mathrm{e}}$ & $1.84^{\mathrm{de}}$ & $0.62^{\mathrm{de}}$ & $0.02^{\mathrm{e}}$ & $0.06^{\mathrm{de}}$ & $0.06^{\mathrm{d}}$ & $0.11^{\mathrm{cd}}$ \\
\hline $\mathbf{I}_{75} \mathbf{F}_{100}$ & $4.60^{\mathrm{abcd}}$ & $6.91^{\mathrm{a}}$ & $5.64^{\mathrm{a}}$ & $6.21^{\mathrm{a}}$ & $0.44^{\mathrm{a}}$ & $0.36^{\mathrm{ab}}$ & $0.28^{\mathrm{b}}$ & $0.34^{\mathrm{a}}$ \\
\hline $\mathbf{I}_{75} \mathbf{F}_{75}$ & $3.17^{\text {bcde }}$ & $5.27^{\mathrm{abc}}$ & $2.44^{\text {cde }}$ & $2.62^{\mathrm{cd}}$ & $0.26^{\mathrm{bcd}}$ & $0.25^{\mathrm{bc}}$ & $0.13^{\mathrm{cd}}$ & $0.21^{\mathrm{abcd}}$ \\
\hline $\mathbf{I}_{\mathbf{7 5}} \mathbf{F}_{\mathbf{5 0}}$ & $3.14^{\text {cde }}$ & $4.43^{\mathrm{abcd}}$ & $1.86^{\mathrm{de}}$ & $2.25^{\mathrm{cde}}$ & $0.13^{\text {cde }}$ & $0.19^{\mathrm{cd}}$ & $0.10^{\mathrm{d}}$ & $0.15^{\mathrm{bcd}}$ \\
\hline $\mathbf{I}_{\mathbf{7 5}} \mathbf{F}_{\mathbf{0}}$ & $2.25^{\mathrm{def}}$ & $1.58^{\mathrm{de}}$ & $1.43^{\mathrm{de}}$ & $0.78^{\mathrm{de}}$ & $0.03^{\mathrm{e}}$ & $0.10^{\mathrm{de}}$ & $0.067^{\mathrm{d}}$ & $0.08^{\mathrm{d}}$ \\
\hline$I_{65} F_{100}$ & $5.81^{\mathrm{a}}$ & $6.74^{\mathrm{a}}$ & $5.98^{\mathrm{a}}$ & $6.53^{\mathrm{a}}$ & $0.46^{\mathrm{a}}$ & $0.40^{\mathrm{a}}$ & $0.43^{\mathrm{a}}$ & $0.34^{\mathrm{a}}$ \\
\hline$I_{65} F_{75}$ & $4.45^{\mathrm{abcd}}$ & $5.74^{\mathrm{ab}}$ & $3.60^{\mathrm{bc}}$ & $3.38^{\mathrm{bc}}$ & $0.27^{\text {bcd }}$ & $0.40^{\mathrm{a}}$ & $0.15^{\mathrm{cd}}$ & $0.26^{\mathrm{abc}}$ \\
\hline $\mathbf{I}_{65} \mathbf{F}_{50}$ & $3.56^{\text {abcde }}$ & $4.76^{\mathrm{abc}}$ & $3.00^{\mathrm{cd}}$ & $3.38^{\mathrm{bc}}$ & $0.22^{\mathrm{bcd}}$ & $0.36^{\mathrm{ab}}$ & $0.11^{\mathrm{d}}$ & $0.12^{\mathrm{cd}}$ \\
\hline $\mathbf{I}_{65} \mathbf{F}_{0}$ & $3.08^{\text {cde }}$ & $2.56^{\text {cde }}$ & $2.30^{\text {cde }}$ & $1.26^{\mathrm{cde}}$ & $0.04^{\mathrm{e}}$ & $0.11^{\mathrm{de}}$ & $0.07^{\mathrm{d}}$ & $0.09^{\mathrm{d}}$ \\
\hline F-test & & & & & & & & \\
\hline Irrigation & $*$ & NS & NS & NS & NS & $*$ & NS & NS \\
\hline Fertilization & $*$ & $*$ & $*$ & $*$ & $*$ & $*$ & $*$ & $*$ \\
\hline Irri. * Fert. & $*$ & $*$ & $*$ & $*$ & $*$ & $*$ & $*$ & $*$ \\
\hline
\end{tabular}


On the other hand, the productivity of TSS, N, P, and K as ton per hectare differs from the previous results. The productivity of TSS, N, P, and K increased with increasing the both of applied water level and NPK application rate. As shown in figure (4), at the same applied water level, the productivities of TSS, N, P, and K increased with increasing NPK application rate. Also the productivities of TSS, N, P, and $\mathrm{K}$ decreased with decreasing applied water. This is due to significant differences in production in relation to treatments of higher applied water compared to lower applied water treatments. The results show that there is no significant effect between the treatments $\mathrm{I}_{100} \mathrm{~F}_{100}$ and $\mathrm{I}_{85} \mathrm{~F}_{100}$ for TSS, N, P, and $\mathrm{K}$.
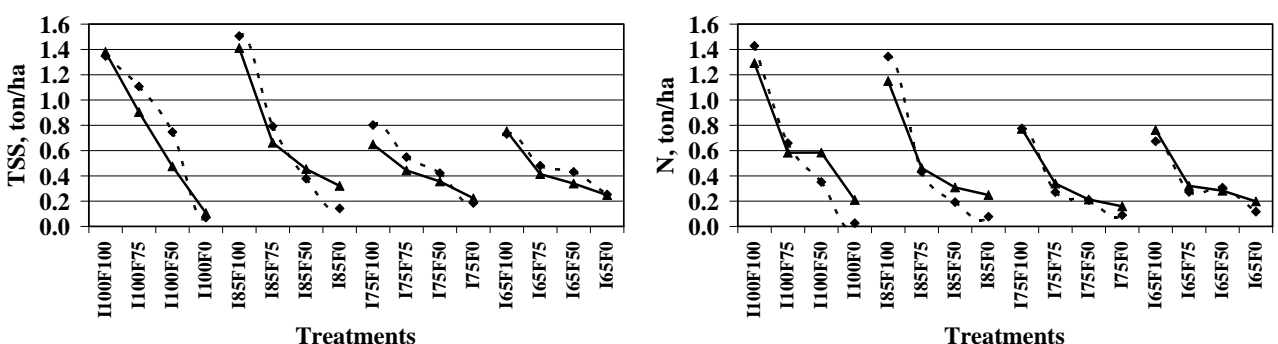

Treatments

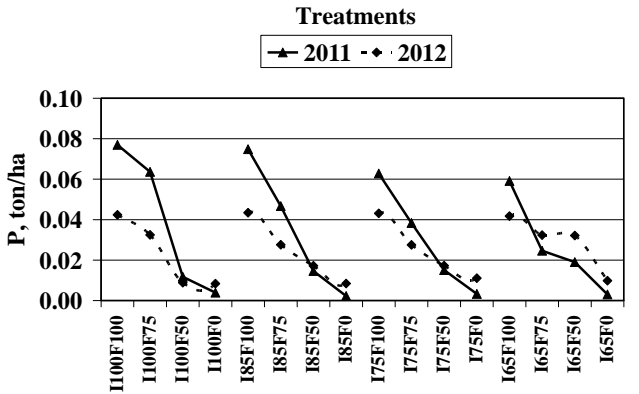

Treatments
$\square-2011-\bullet 2012$
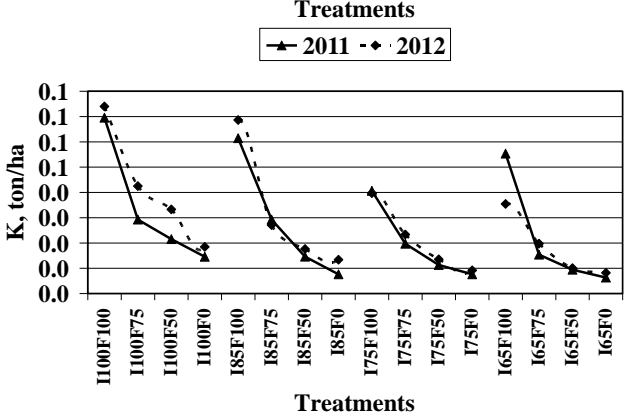

$\rightarrow 2011-\bullet 2012$

\section{Figure (4): The productivity of TSS, N, P, and K as ton per hectare} under different applied water levels and NPK application rates.

The relationships of TSS, N, P, and K to different water levels and NPK rates were studied. The greatest effect of increasing applied water was the curvilinear rise in total yield, marketable yield, dry bulb yield, total dry biomass, WUE $\mathrm{y}_{\mathrm{y}}$ and $\mathrm{WUE}_{\mathrm{m}}$ in both seasons (Figures 2 and 3). Conversely, a negative trend in response to increased applied water was described for TSS, N, P, and $\mathrm{K}$ in both seasons. There were parabolic correlations 
between total yield, marketable yield, dry bulb, biomass yield, TSS, N, P, $\mathrm{K}, \mathrm{WUE}_{\mathrm{y}}$ and $\mathrm{WUE}_{\mathrm{m}}$ under different water level and NPK fertilization treatments.

2011
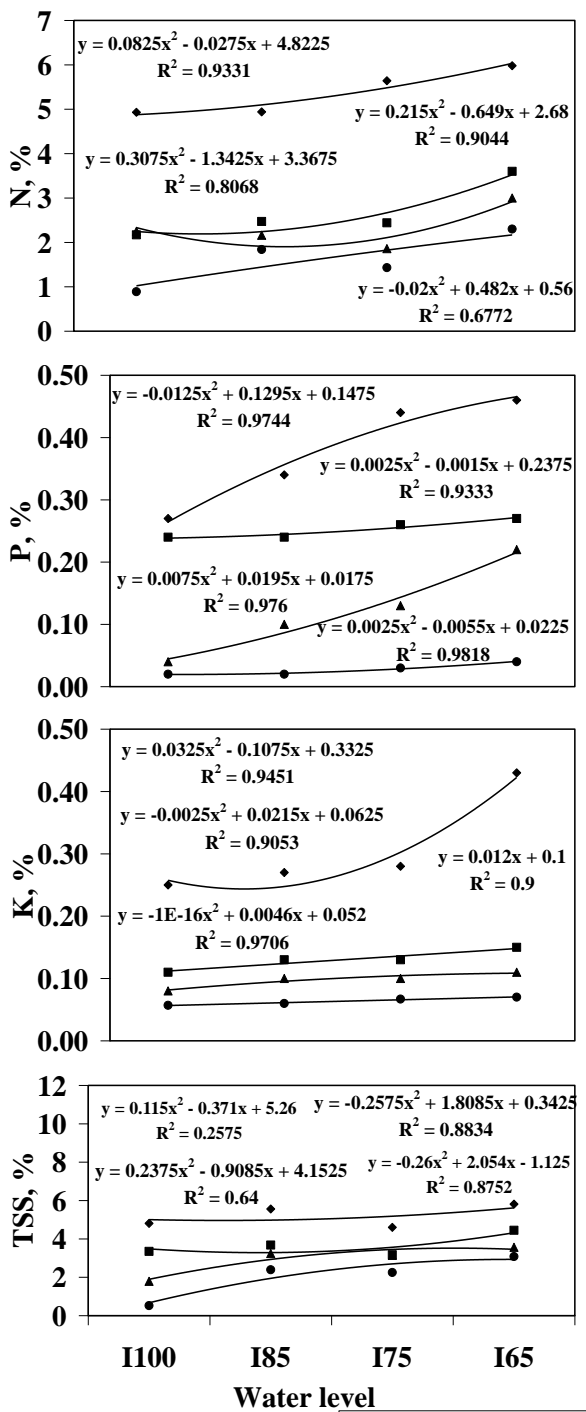

2012
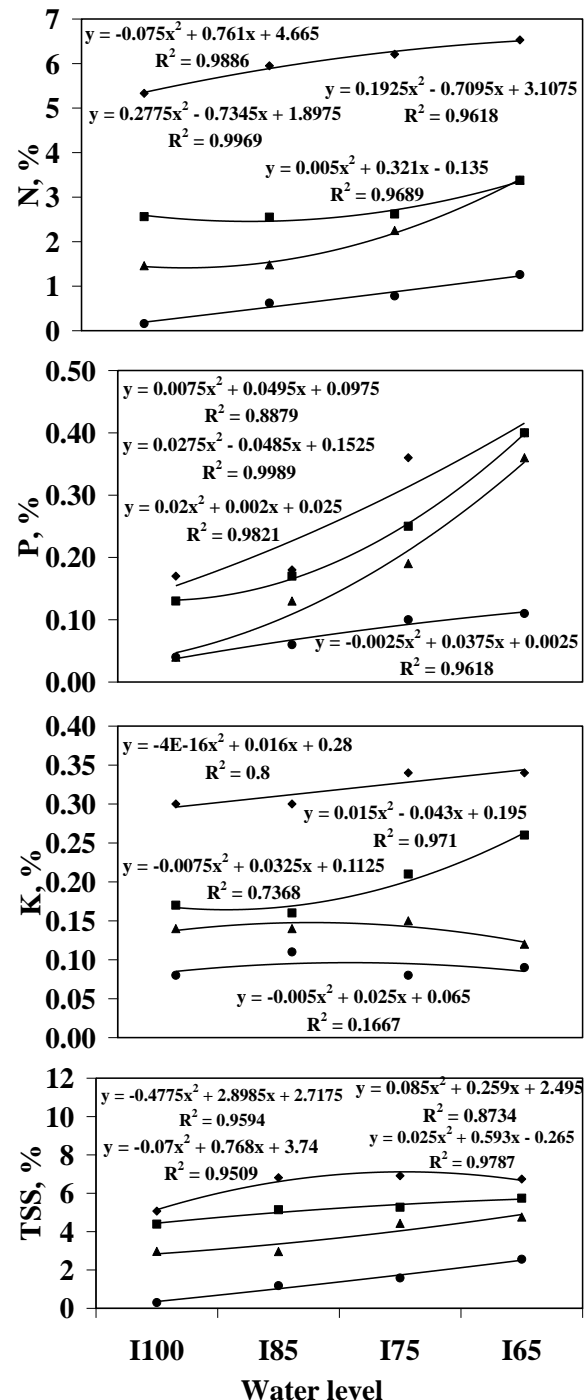

Water level

• NPK100 • NPK75 ^ NPK50 • NPK0

Figure (2): Correlations between TSS, N, P, K, and water levels at different NPK rates in seasons 2011 and 2012. 
The results also indicated that NPK application had greater effect on quality parameters of onion compared to water level effect. At the same water level, the percentage of TSS, N, P, and K decreased significantly with decreasing NPK rate especially at 0 and $50 \%$ NPK. Total soluble solids (TSS) content in onion bulbs was higher in $\mathrm{I}_{65} \mathrm{~F}_{100}$ treatment than $\mathrm{I}_{100} \mathrm{~F}_{100}$ and other treatments. Singh and Dhankar (1989) reported increases in TSS content with increased in potassium levels and ascribed to increased production of carbohydrates during photosynthesis. The present results corroborate the findings of Vacchani and Patel (1993), Yadav et al., (2002) and Singh (2000). Similar trend results were observed with N, $\mathrm{P}$, and $\mathrm{K}$ (table 5). These results corroborate the findings of earlier workers (Nagaich et al., 1998 and Girigowda et al., 2005) in onion cultivated under a wide range of NPK application treatments, which return the reason to the uptake of $\mathrm{N}, \mathrm{P}$, and $\mathrm{K}$ at harvest increased with increase in dosage of potassium. The increased uptake of these nutrients could be attributed to increased dry matter production under balanced supply of nutrients.

\section{The results showed that:}

\section{CONCLUSION}

1. In 2011, significantly higher marketable bulb yields $(25.41,24.13$, 23.72 and 19.68 ton/ha) were obtained with $\mathrm{I}_{100} \mathrm{~F}_{100}, \mathrm{I}_{100} \mathrm{~F}_{75}, \mathrm{I}_{100} \mathrm{~F}_{50}$ and $\mathrm{I}_{100} \mathrm{~F}_{0}$ treatments, respectively. In 2012, significantly higher marketable bulb yields $(24.81,23.49,20.68$ and 22.52 ton/ha) were obtained with $\mathrm{I}_{100} \mathrm{~F}_{100}, \quad \mathrm{I}_{100} \mathrm{~F}_{75}, \quad \mathrm{I}_{100} \mathrm{~F}_{50}$, and $\mathrm{I}_{85} \mathrm{~F}_{100}$ treatments, respectively.

2. In 2011 , significantly higher dry matter production $(2.175,1.770$, 1.548 , and 1.611 ton/ha) were obtained with $\mathrm{I}_{100} \mathrm{~F}_{100}, \mathrm{I}_{100} \mathrm{~F}_{75}, \mathrm{I}_{100} \mathrm{~F}_{50}$, and $\mathrm{I}_{75} \mathrm{~F}_{100}$ treatments, respectively. In 2012, significantly higher dry matter production $(1.749,1.674,1.640$, and 1.692 ton/ha) were obtained with the same treatments, respectively.

3. Decreasing the water level from $100 \% \mathrm{ET}_{\mathrm{c}}$ to $85 \% \mathrm{ET}_{\mathrm{c}}$, in treatment $\mathrm{I}_{85} \mathrm{~F}_{100}$ decreased non significantly the $\mathrm{WUE}_{\mathrm{y}}$ by about $7.93 \%$ in 2011 while increased by about $6.44 \%$ in 2012 when compared to treatment $\mathrm{I}_{100} \mathrm{~F}_{100}$. 
4. Decreasing the water level from $100 \% \mathrm{ET}_{\mathrm{c}}$ to $85 \% \mathrm{ET}_{\mathrm{c}}$, in treatment $\mathrm{I}_{85} \mathrm{~F}_{100}$ decreased non significantly the $\mathrm{WUE}_{\mathrm{m}}$ by about $16.41 \%$ in 2011 while increased by about $6.14 \%$ in 2012 when compared to treatment $\mathrm{I}_{100} \mathrm{~F}_{100}$.

5. Decreasing the NPK rate from $100 \%$ to $75 \%$, in treatment $\mathrm{I}_{100} \mathrm{~F}_{75}$ decreased non significantly the $\mathrm{WUE}_{\mathrm{y}}$ by about 2.85 and $2 \%$ when compared to treatment $\mathrm{I}_{100} \mathrm{~F}_{100}$ in 2011 and 2012, respectively, while WUE $_{\mathrm{m}}$ was decreased by about 5.1 and 5. ₹0\% when compared to treatment $\mathrm{I}_{100} \mathrm{~F}_{100}$, in 2011 and 2012, respectively.

6. TSS, N, P, and $\mathrm{K}$ percentages of onion bulb increased significantly with decreasing applied water level and with increasing NPK rate in the two seasons but the productivity of TSS, N, P, and $\mathrm{K}$ as ton per hectare was increased with increasing both applied water level and NPK application rate.

\section{REFERENCES}

AOAC, 2000. Official method 920.183 (b) Sugars (Reducing) in Honey/ I.S.I Hand book of Food Analysis (Part II) - 1984 page 36.

Bazza, M., 1994. Identification of wheat varieties suitable for arid and semi-arid conditions and of the characters for selection and breeding in regard to water-use efficiency. Kluwer Academic Publishers, Netherlands.

Bungard R. A.; A Wingler; J. D. Morton and M. Andrews. 1999. Ammonium can stimulate nitrate and nitrite reductase in the absence of nitrate in Clematis vitalba. Plant Cell Environ., 22: 859866.

Camposeo, S. and P. Rubino. 2003. Effect of irrigation frequency on root water uptake in sugar beet. Plant Soil 253 (2), 301-309.

English, M. J.; J. T. Musick and V. V. N. Murty. 1990. Deficit irrigation. Management of Farm Irrigation Systems. ASAE Monograph, Michigan. pp. 631-663.

Enciso, J. M.; B. Wiedenfeld; J. Jifon and S. Nelson. 2009. Onion yield and quality response to two irrigation scheduling strategies. Scientia Horticulturae 120 (2009) 301-305. 
Favati, F.; S. Lovelli; F. Galgano; V. Miccolis; T. Di Tommaso and V. Candido. 2009. Processing tomato quality as affected by irrigation scheduling. Sci. Hortic. 122, 562-571.

Geerts, S.; D. Raes; M. Garcia; J. Vacher; R. Mamani; J. Mendoza; R. Huanca; B. Morales; R. Miranda; J. Cusicanqui and C. Taboada. 2008. Introducing deficit irrigation to stablize yields of quinoa (Chenopodium quinoa Willd.). Eur. J. Agron. 28: 427-436.

Girigowda, J. R.; N. C. Narasegowda and H. C. Krishna. 2005. Effect of fertilizer levels on uptake of primary nutrients and bulb yield of onion hybrids. Mysore J. Agric. Sci. 39(4): 557 - 560.

Gubb I.R, and M. S. H. Tavish. 2002. Onion preharvest and postharvest considerations. In: Rabinowitch HD, Currah L (eds.). Allim crop science. CABI publishing, UK. pp. 237-250.

Hanson, B.; D. May; R. Voss; M. Cantwell and R. Rice. 2003. Response of garlic to irrigation water. Agric. Water Manage. 58 (1), 29-43.

Hedge, D.M., 1986. Effect of irrigation regimes on dry matter production, yield, nutrient uptake and water use of onion. Ind. J. Agron. 31, 343 -348 .

Imtiyaz, M.; N. P. Mgadla; B. Chepete and S. K. Manase. 2000. Response of six vegetable crops to irrigation schedules. Agric. Water Manage. 45 (3), $331-342$.

Jordan, J. E.; R. H. White; D.M. Victor; T.C. Hale; J.C. Thomas and M. C. Engelke. 2003. Effect of irrigation frequency on turf quality, shoot density, and root length density of five bentgrass cultivars. Crop Sci. 43 (1), 282-287.

Kirda, C., 2000. Deficit irrigation scheduling based on plant growth stages showing water stress tolerance. Deficit Irrigation Practices, FAO Water Reports, Rome 22.

Kumar, S.; M. Imtiyaz; A. Kumar and R. Singh. 2007. Response of onion (Allium cepa L.) to different levels of irrigation water. Agricultural Water Management 89: 161-166.

Lovelli, S.; M. Perniola; A. Ferrara and T. Di Tommaso. 2007. Yield response factor to water $(\mathrm{Ky})$ and water use efficiency of Carthamus 
tinctorius L. and Solanum melongena L. Agric. Water Manage. 92, 73-80.

Martin de Santa Olalla, F.J.; G. A. de Juan Valero and C. Fabeiro Corte`s. 1994. Growth and production of onion crop (Alium cepa L.) under different irrigation schedulings. Eur. J. Agron. 3 (1), 85 -92.

Nagaich, K. N.; S. K. Tridevi and Fajesh Lekhi. 1998. Effect of sulphur and potassium fertilization on onion (Allium cepa L.). South Indian Hort., 46(5 \& 6): 266 - 271.

Ozbahce, A. and A. F. Tari. 2010. Effects of different emitter space and water stress on yield and quality of processing tomato under semiarid climate conditions. Agric. Water Manage. 97, 1405-1410.

Samson, B. and K. Tilahun. 2007. Regulated deficit irrigation scheduling of onion in a semiarid region of Ethiopia. Agricultural Water Management. 89 (2007) 148-152.

Shock, C.C.; E.B.G. Feibert and L.D. Saunders. 2000. Irrigation criteria for drip-irrigated onions. HortScience 35:63-66.

Singh, J. and B. S. Dhankar. 1989. Effect of nitrogen, potash and zinc on storage of onion bulbs (Allium cepa). Veg. Sci., 18(1): 16 - 23.

Singh, R. B. and S. B. Singh. 2000. Significance of nitrogen, phosphorus and potassium on onion (Allium cepa L.) raised from onion sets (Bulblets). Veg. Sci., 27(1): $88-89$.

Singh, S.; P. K. Yadav and B. Singh. 2004. Effect of nitrogen and potassium on growth and yield of onion (Allium cepa L.) Cv. Pusa Red. Haryana J. Hort. Sci., 33(3 \& 4): 308 - 309.

Steduto, P.; T. C. Hsiao; D. Raes and E. Fereres. 2009. Aqua Crop. The FAO Crop Model to Simulate Yield Response to Water: I. Concepts and Underlying Principles. Agron. J. 101: 426-437.

Vacchani, M. V. and Z. G. Patel. 1993. Effect of nitrogen phosphorus and potash on bulb yield and quality of onion (Allium cepa L.). Indian J. Agron., 32(2): 333 - 334.

Yadav, R. L.; N. L. Sen; M. S. Fageria and R. S. Dhaka. 2002. Effect of nitrogen and potassium fertilization on quality bulb production of onion. Haryana J. Hort. Sci. 31(3\&4): 297-298. 
Zwart, S. J. and W. G. M. Bastiaanssen. 2004. Review of measured crop water productivity values for irrigated wheat, rice, cotton and maize. Agric. Water Manage 69:115-133.

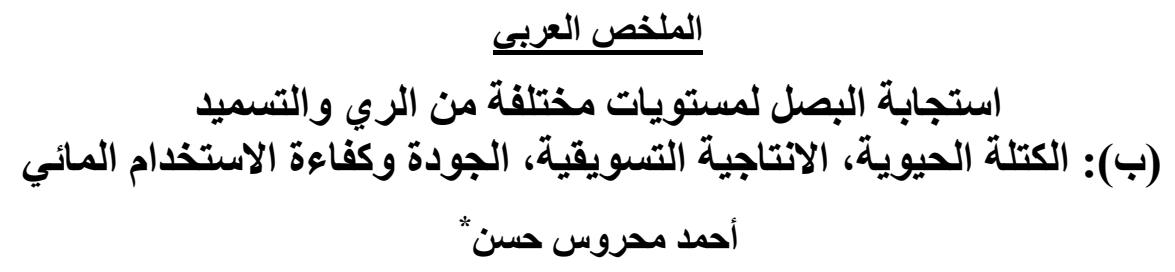

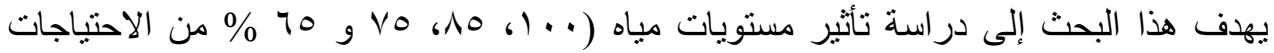

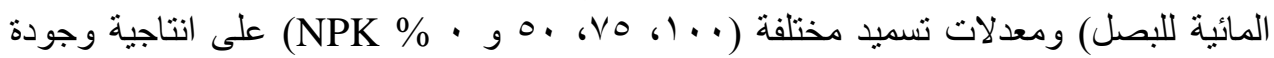
محصول البصل. وقد توصلت الدر اسة على على ما يلي:

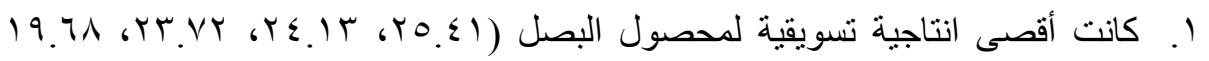
طن/هكتار) للمعاملات

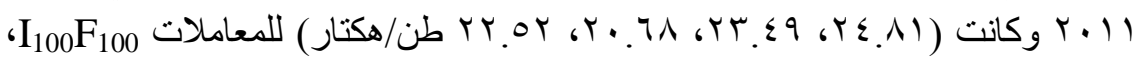

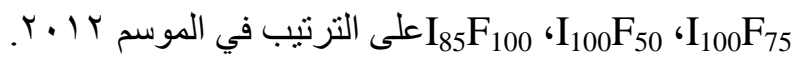

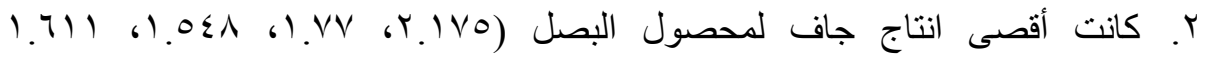
طن/هكتار) للمعاملات 1

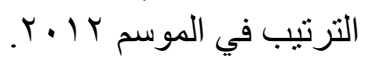

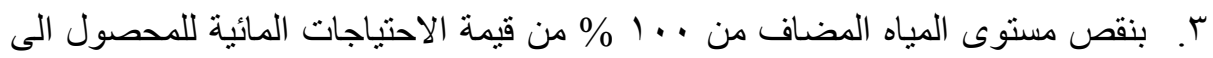

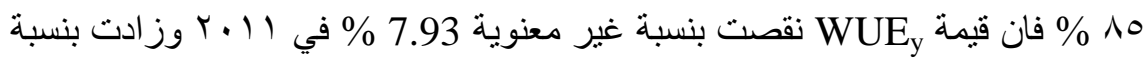

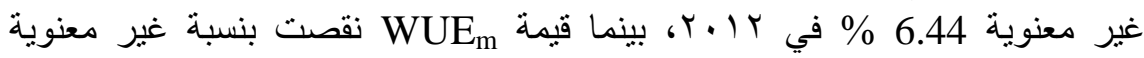

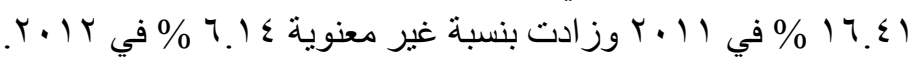

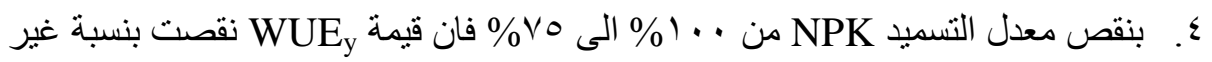

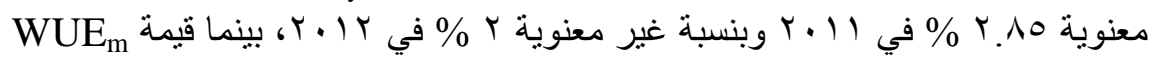

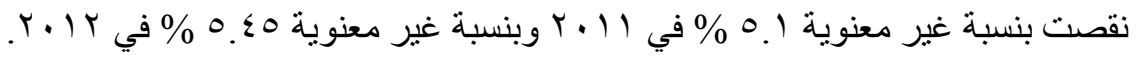

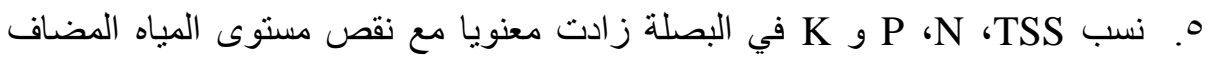

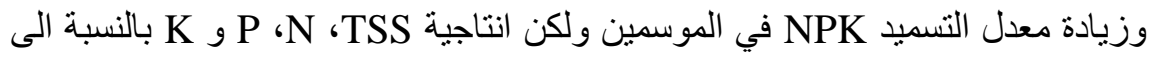
الهكتار زادت بزيادة كل من مستوى المياه المضاف ومعدل التسميد NPK. 